УДК 347.721

DOI https://doi.org/10.32849/2663-5313/2020.5.10

Ігор Галіян, аспірант відділу проблем приватного права

Науково-дослідного інституту приватного права і підприємництва імені академіка Ф.Г. Бурчака Начіональної академії правових наук України

\title{
ВИЗНАННЯ НЕДІЙСНИМИ РІШЕНЬ ОРГАНІВ УПРАВЛІННЯ ГОСПОДАРСЬКИМ ТОВАРИСТВОМ ЯК СПОСІБ ЗАХИСТУ КОРПОРАТИВНИХ ПРАВ
}

У статті акиентовано увагу на спеиифіиі застосування такого способу захисту корпоративних прав, як визнання недійсними рішень органів управління господарським товариством. Обгрунтовано його дієвість та доиільність виділення в межах інших способів захисту. Акиентовано увагу на розмежуванні повноважень загальних зборів і виконавчого органу в системі органів управління господарським товариством. Констатовано превалювання у вітчизняному законодавстві повноважень загальних зборів над іншими органами товариства.

Встановлено, що безумовними підставами для застосування такого способу захисту, як право вимагати визнання недійсними рішень органів управління господарського товариства, можуть бути: відсутність кворуму на загальних зборах; порушення порядку їх скликання, прийняття зборами рішень з питань, які не були внесені до порядку денного; проведення зборів в іншому місиі та в інший час, ніж ие було вказано у повідомленні; відсутність протоколу загальних зборів ТОВ; відсутність протоколу загальних зборів АT, підписаного головою і секретарем зборів тощо. Формальними підставами для застосування ивого способу захисту може бути недопуск учасника до участі в загальних зборах, коли прийняте рішення призвело до заподіяння збитків такому учасникові тощо.

Доведено, що застосування иього способу захисту без належних на те підстав може призводити до блокування важливих для діяльності товариства рішень, що негативно відображатимуться на його підприємницькій діяльності. Саме тому право на оскарження рішень органів господарського товариства підлягає впливу закріплених законодавчо обмежень, що передбачають дотримання таких умов, як невідповідність рішень загальних зборів нормам законодавства; порушення вимог закону та/або установчих документів під час скликання та проведення загальних зборів товариства; позбавлення учасника товариства можливості взяти участь у загальних зборах. Наведені умови мають переважно процедурний характер та не завжди є підставою для визнання недійсними прийнятих на загальних зборах рішень.

У статті акцентовано увагу на правовій природі рішень органів управління господарських товариств як актів ненормативного характеру. До рішень загальних зборів учасників господарського товариства не можуть застосовуватися положення ст. 203 та 215 ЦК України, які визначають підстави недійсності правочину, $i$, відповідно, правові наслідки недійсності правочину за ст. 216 ЦК України. Запропоновано класифікачію рішень органів управління господарських товариств за критерієм істотності допущеного порущення та їх наслідків.

Ключові слова: корпоративне право, орган управління господарського товариства, спосіб захисту, рішення загальних зборів, рішення виконавчого органу, підстави застосування способу захисту, оскарження рішень загальних зборів.

Постановка проблеми. Право брати участь в управлінні господарським товариством як немайнове (організаційне) право нерозривно пов'язане 3 іншими немайновими та майновими корпоративними правами учасника, що зумовлює і те, що деякі способи захисту виявляються універсальними для захисту як немайнових, так і майнових прав. Водночас сутність внутрішньогосподарських відносин, що виникають між учасниками товариства, самим товариством, його органами, свідчить про нагальну потребу у вирішенні теоретико-прикладної проблеми пошуку найбільш ефективних для цих відносин способів захисту.

Дієвим способом захисту прав учасників господарських товариств, що випливають 3 управління товариством, $є$ право вимагати визнання недійсними рішень органів управління господарського товариства. Доцільність виділення цього способу захисту, що випливає $з$ участі в товаристві, підтверджується висловленою I. Р. Калауром позицією про свого роду умовний поділ корпоративних прав на більш дрібні права, які стало загальноприйнятим поділяти на два складника - 
майнові та організаційні. Такий поділ, на думку вченого, є певною мірою умовним, але зручним для уявлення про ті можливості, яких набувають особи, вкладаючи (інвестуючи) свій капітал в господарське товариство. Водночас, звісно, ніхто з практиків не замислювався над правовою природою участі в загальних зборах та вимоги про виплату дивідендів [1, с. 36].

Так, чинним законодавством передбачено можливість оскарження до суду учасниками господарських товариств рішень різних органів управління товариства (загальних зборів, наглядової ради, виконавчого органу тощо). Водночас науковий інтерес викликає питання розмежування повноважень загальних зборів і виконавчого органу в системі органів управління господарським товариством. Наприклад, в англо-американському праві простежується зміщення акцентів у бік посилення ролі ради директорів. Натомість аналіз норм вітчизняного законодавства (ч. 1 ст. 33 Закону України «Про акціонерні товариства», ч. 1 ст. 29 Закону України «Про товариства з обмеженою та додатковою відповідальністю» тощо) дозволяє констатувати превалювання повноважень загальних зборів над іншими органами товариства.

Виклад основного матеріалу. Як видається, закріплений законодавчий підхід також не завжди є виправданим на практиці. Особливо якщо це стосується акціонерних товариств зі значною кількістю акціонерів, процедура скликання яких є досить витратною та довготривалою, що серйозно ускладнює швидке реагування товариства на ринкову ситуацію (швидке укладення економічно вигідних договорів, викуп товариством власних акцій, використання додаткової емісії акцій як способу фінансування тощо). Крім того, сьогодні доводиться констатувати зниження інтересу більшості міноритарних акціонерів до участі в роботі загальних зборів. Виконавчий орган товариства вирішує більшість найважливіших питань, які лише формально затверджуються на загальних зборах акціонерів, які здебільшого мають формальний характер, на яких декілька представників за довіреністю представляють інтереси всіх акціонерів, фактично затверджують прийняті виконавчим органом рішення щодо управління товариством. Недарма в юридичній літературі висловлюються пропозиції щодо доцільності перегляду співвідношення компетенції загальних зборів та інших органів управління товариством шляхом наділення загальних зборів правом делегувати свої повноваження виконавчому органу управління [2, с. 153].
Як видається, такий спосіб захисту спрямований на нівелювання можливих наслідків порушень корпоративних прав учасника у майбутньому шляхом визнання рішень конкретного органу управління (загальних зборів, ради директорів тощо) недійсними до моменту їх застосування. На практиці непоодинокими є випадки порушення прав учасників товариства недобросовісними, умисними діями керівних органів товариства шляхом, наприклад, випуску акцій додаткової емісії, умисним доведенням до банкрутства та виведенням ліквідних активів із товариства тощо.

Отже, право учасників товариства оскаржувати рішення виконавчого органу товариства закріплено на конституційному рівні (ст. 55 Конституції України) за аналогією 3 визнанням недійсними рішень загальних зборів, однак з урахуванням специфіки діяльності ради директорів, наглядової ради тощо. Наприклад, рішення, прийняті з порушенням компетенції органу, за відсутності кворуму для проведення засідання, якщо наявність кворуму $є$ обов'язковою умовою для його проведення, або без необхідної для прийняття рішення більшості голосів, слід вважати нікчемними [3, с. 529].

Загалом такі рішення органів управління господарського товариства, що спрямовані на порушення прав їх учасників, визнаються недійсними за умови доведеності підстав їх недійсності. У законодавстві України хоча би приблизний перелік таких підстав відсутній. Натомість на доктринальному рівні на необхідності встановлення таких підстав наголошувалося неодноразово [4, с. 23; 5, с. 7].

Відповідно, безумовними підставами для застосування такого способу захисту, як право вимагати визнання недійсними рішень органів управління господарського товариства, можуть бути: відсутність кворуму на загальних зборах; порушення порядку їх скликання, прийняття зборами рішень 3 питань, які не були внесені до порядку денного; проведення зборів в іншому місці та в інший час, ніж це було вказано у повідомленні; відсутність протоколу загальних зборів ТОВ; відсутність протоколу загальних зборів АТ, підписаного головою і секретарем зборів тощо. Натомість формальними підставами для застосування цього способу захисту може бути недопуск учасника до участі в загальних зборах, коли прийняте рішення призвело до заподіяння збитків такому учасникові тощо.

Разом із тим передбачити на законодавчому рівні всі підстави, що призводять до застосування такого способу захисту, як право вимагати визнання недійсними рішень 
органів управління господарського товариства, не можливо. Більше того, порушення права на участь учасника в управлінні товариством може призводити й до використання таких способів захисту, як, наприклад, вимагати від АТ здійснення обов'язкового викупу належних йому акцій (ст. 68 Закону України «Про акціонерні товариства») чи, навпаки, спонукання акціонера до реалізації належного йому права на управління AT шляхом участі в загальних чи позачергових зборах товариства (ч. 1 ст. 29 Закону України «Про акціонерні товариства»).

Щодо правової природи рішень органів управління господарських товариств доцільно наголосити на єдності розуміння на практиці природи таких рішень, як акти ненормативного характеру. Прикладом зазначеного є відображені в постановах КГС ВС від 20.03.2018 у справі № 916/375/17 [6], від 02.05.2018 у справі № 910/807/17 [7], від 16.10.2018 у справі № 920/1101/17 [8] правові позиції, в яких під рішеннями загальних зборів господарських товариств розуміються акти ненормативного характеру (індивідуальні акти), тобто офіційні письмові документи, що породжують певні правові наслідки, які спрямовані на регулювання господарських відносин і мають обов'язковий характер для суб'єктів цих відносин. Не $€$ рішення загальних зборів учасників господарського товариства і договором, тому що приймається не за домовленістю всіх учасників товариства, а більшістю їхніх голосів [9]. До рішень загальних зборів учасників господарського товариства не можуть застосовуватися положення ст. 203 та 215 ЦК України, які визначають підстави недійсності правочину, і, відповідно, правові наслідки недійсності правочину за ст. 216 ЦК України.

Разом із тим застосування досліджуваного способу захисту без належних на те підстав може призводити до блокування важливих для діяльності товариства рішень, що негативно відображатимуться на його підприємницькій діяльності та впливатимуть на стабільність майнового обороту. Саме тому право на оскарження рішень органів господарського товариства підлягає впливу закріплених законодавчо обмежень, що передбачають дотримання цілого ряду умов, найбільш загальні з яких закріплено у Постанові Пленуму Вищого Господарського Суду України від 22.02.2016 (невідповідність рішень загальних зборів нормам законодавства; порушення вимог закону та/або установчих документів під час скликання та проведення загальних зборів товариства; позбавлення учасника (акціонера, члена) товариства можливості взяти участь у загальних збо- рах). Вказані умови, як слушно зазначається в юридичній літературі, мають переважно процедурний характер та не завжди є підставою для визнання недійсними прийнятих на загальних зборах рішень [3, с. 526].

Насамперед правом на оскарження рішень органів господарського товариства можуть скористатися виключно учасники господарського товариства як носії суб'єктивних корпоративних прав. Тобто особа, втративши статус учасника господарського товариства, автоматично втрачає право вимагати визнання недійсними рішень органів управління товариства. Відповідно, оскаржити рішення органу управління товариства може лише особа, яка $є$ учасником господарського товариства як на момент прийняття оскаржуваного рішення, так і на момент розгляду судом відповідного позову.

Щодо давньої дискусії про надання права на оскарження рішень загальних зборів особам, які до моменту подачі позову про оскарження рішення відступили свої права на акції (частки) третій особі, доцільно зазначити, що законодавець у ст. 50 Закону України «Про акціонерні товариства» передбачив чітке правило, за яким можливість оскарження актів органів юридичної особи, якщо рішення загальних зборів або порядок прийняття такого рішення порушують вимоги цього Закону, інших актів законодавства, статуту чи положення про загальні збори акціонерного товариства, належить виключно акціонеру. Зазначене положення знайшло своє належне відображення й на практиці, де усталеним є правило, за яким з моменту виходу з товариства учасник втрачає право брати участь в управлінні товариством [10;11].

Крім того, право оскаржити рішення загальних зборів має учасник господарського товариства, який не брав участі в загальних зборах або голосував проти прийняття такого рішення. Особами, які брали участь у загальних зборах, є учасники, що зареєструвалися для участі в ньому, а також учасники, що взяли участь у загальних зборах шляхом надання свого волевиявлення щодо голосування з питань порядку денного у письмовій формі (заочне голосування). Рішення загальних зборів учасників приймаються відкритим голосуванням, якщо інше не передбачено статутом товариства. У зв'язку з цим на практиці можливі різні зловживання шляхом, наприклад, блокування доступу в зал вже зареєстрованих учасників, що позбавляє їх права на оскарження прийнятих за їх фактичної відсутності рішень. Така поведінка позбавляє як самого учасника, так і господарське товариство можливості приймати 
рішення з питань, віднесених до компетенції загальних зборів, які потребують визначеної законом кількості голосів

Отже, зважаючи, що порядок скликання та проведення загальних зборів учасників товариства передбачено абсолютно імперативними нормами, відповідно, й суперечливі їм рішення можуть бути визнані недійсними. Так, за критерієм істотності допущеного порушення абсолютно імперативних норм корпоративного законодавства при прийнятті рішення як на доктринальному, так і правозастосовчому рівнях виділяють дві групи недійсних рішень, відмінність між якими полягає у різних правових наслідках.

До першої групи віднесені рішення, прийняті: 1) за відсутності кворуму для проведення загальних зборів чи прийняття рішення або у разі неможливості встановлення наявності кворуму (ст. 41, 42 Закону України «Про акціонерні товариства», ст. 33, 34, 35, 36 Закону України «Про товариства 3 обмеженою та додатковою відповідальністю», ст. 15 Закону України «Про кооперацію»); 2) з питань, не включених до порядку денного загальних зборів товариства (ч. 6 ст. 42 Закону України «Про акціонерні товариства», ч. 5 ст. 33 Закону України «Про товариства 3 обмеженою та додатковою відповідальністю»); 3) без ведення протоколу загальних зборів товариства (ст. 46 Закону України «Про акціонерні товариства», ч. 4 ст. 33 Закону України «Про товариства 3 обмеженою та додатковою відповідальністю»).

Вищенаведені порушення абсолютно імперативних норм та, відповідно, застосування такого способу захисту, як визнання рішень органів управління недійсними, спрямовано на закріплення та врахування саме належного волевиявлення учасників господарського товариства, тому такі рішення не мають сили незалежно від оскарження їх у судовому порядку та іменуються в юридичній літературі нікчемними [3, с. 527; 12 , с. 353]

До другої групи недійсних рішень загальних зборів належать всі інші рішення, які можуть бути визнані недійсними в судовому порядку. Такі рішення втрачають юридичну силу 3 моменту прийняття відповідного рішення судом. Здебільшого такі порушення мають процедурний характер: наприклад, учасник не був належним чином сповіщений про дату проведення загальних зборів; йому не була надана можливість ознайомитися 3 необхідною інформацією з питань, включених до порядку денного зборів; бюлетені для голосування були надані несвоєчасно тощо.

Як видається, $з$ точки зору правозастосовувача кваліфікація поведінки учасника, який ухиляється від участі в загальних збоpax, як корпоративного правопорушення чи зловживання правом має однаковий правовий наслідок - відмова в позові про захист права такого учасника. Як наголошується 3 цього приводу в юридичній літературі, подання позовів про спонукання до участі в загальних зборах може використовуватися як інструмент дестабілізації діяльності товариства. Закон України «Про господарські товариства» не встановлює імперативних норм, які зобов'язували б учасника до участі в управлінні товариством, що є логічним 3 огляду на економіко-правову сутність корпорацій як об'єднання капіталів (на відміну, зокрема, від обов'язку майнової участі учасника у статутному капіталі товариства) $[13$, c. 252$]$

Так, серед передбачених в ст. 29 Закону України «Про акціонерні товариства» обов'язків про обов'язок акціонера участі у загальних зборах взагалі не йдеться. Більше того, відповідно до внесених у 2017 році Законом України «Про внесення змін до деяких законодавчих актів України щодо корпоративних договорів» змін до Закону України «Про акціонерні товариства» Розділ V «Права та обов'язки акціонерів» доповнено ст. 26-1, ч. 1 якої передбачено можливість акціонерів закріпити в договірному порядку (акціонерний договір) спільний обов'язок голосувати у спосіб, передбачений таким договором, на загальних зборах акціонерів товариства, погоджувати придбання або відчуження акцій за заздалегідь визначеною ціною та/або у разі настання визначених у договорі обставин, утримуватися від відчуження акцій до настання визначених у договорі обставин, а також вчиняти інші дії, пов'язані з управлінням товариством, його припиненням або виділом 3 нього нового товариства. Натомість частиною другою цієї ж статті умову договору про зобов'язання акціонера голосувати згідно 3 вказівками органів управління товариства, щодо акцій якого укладений цей договір, крім випадків, якщо стороною договору є особа, яка одночасно входить до складу органу управління такого товариства, визнано нікчемною.

Таким чином, зважаючи на зміст ст. 26-1 Закону України «Про акціонерні товариства», обов'язок акціонера щодо участі в загальних зборах товариства може бути передбачений виключно шляхом його закріплення в договірному порядку і не випливає зі змісту корпоративних прав та не змінюе ï законодавчо визначений зміст. Відповідно, суд може захистити право учасника на управління товариством у спосіб, передбачений договором між акціонерами. Зазначене 
підтверджується висловленою в юридичній літературі тезою, що поза межами акціонерної угоди відсутні будь-які підстави стверджувати, що один 3 акціонерів може вимагати від іншого акціонера певної поведінки (участь у загальних або позачергових загальних зборах) або що праву одного акціонера кореспондує обов’язок іншого акціонера. Таким чином, захист права акціонера на участь в управлінні товариством має власний правовий механізм, оскільки зобов'язаною стороною в таких відносинах виступає саме товариство, а не інший акціонер [13, с. 253]. Відповідно, у разі відсутності договірного застереження про обов'язок учасника брати участь у роботі загальних зборів позов про зобов'язання до такої участі не може розглядатися як ефективний спосіб захисту права учасника на управління товариством.

\section{Висновки}

Отже, право брати участь в управлінні господарським товариством як немайнове (організаційне) право нерозривно пов'язане з іншими немайновими та майновими корпоративними правами учасника, що зумовлюе і те, що деякі способи захисту виявляються універсальними для захисту як немайнових, так і майнових прав. Дієвим способом захисту прав учасників господарських товариств, що випливають 3 управління товариством, є право вимагати визнання недійсними рішень органів управління господарського товариства.

\section{Список використаних джерел:}

1. Охорона прав суб'єктів корпоративних відносин : монографія / Луць В. В., Васильєва В. А., Вінник О. М., Кобецька Н. Р., Калаур I. Р., Саракун І. Б. та ін. ; за заг. ред. Луця В. В. Київ, 2013. C. 36 .

2. Хорт Ю. В. Статутний капітал акціонерного товариства: захист інтересів учасників акціонерних правовідносин : монографія. Харків: Вид-во «ФIHH», 2010. C. 153.

3. Корпоративне право України: проблеми теорії та практики : монографія / В. А. Васильєва, А. В. Зеліско, В. В. Луць, І. Б. Саракун, Л. В. Сіщук та ін. ; за заг. ред. проф. В. А. Васильєвої. ІваноФранківськ: Супрун В. П., 2017. С. 529.
4. Спасибо-Фатєєва I. В. Цивільно-правові проблеми акціонерних правовідносин : дис. ... докт. юрид. наук : 12.00.03. Харків, 2000. С. 23.

5. Щербина О. В., Кібенко О. Р. Чи можна визнати недійсними рішення установчих зборів акціонерного товариства. Підприємництво, господарство і право. 2003. № 5. С. 7.

6. Постанова Верховного Суду у складі колегії суддів Касаційного господарського суду від 20.03.2018 у справі № 916/375/17. URL: http://reyestr.court.gov.ua/Review/72882359 (дата звернення: 21.02.2019).

7. Постанова Верховного Суду у складі колегії суддів Касаційного господарського суду від 02.05.2018 у справі № 910/807/17.3 URL: http://reyestr.court.gov.ua/Review/73840213 (дата звернення: 21.02.2019).

8. Постанова Верховного Суду у складі колегії суддів Касаційного господарського суду від 16.10.2018 у справі № 920/1101/17. URL: http://reyestr.court.gov.ua/Review/77247869 (дата звернення: 21.02.2019).

9. Постанова Верховного Суду у складі колегії суддів Касаційного господарського суду від 12.04.2018 у справі № 922/2688/17. URL: http://reyestr.court.gov.ua/Review/73441777 (дата звернення: 21.02.2019).

10. Постанова Пленуму Вищого Господарського Суду України «Про деякі питання практики вирішення спорів, що виникають 3 корпоративних правовідносин» від 22.02.2016 № 4. URL: http://www.arbitr.gov. ua /files/pages/ppVGSU_25022016_4.pdf (дата звернення: 05.03.2019).

11. Огляд за результатами вивчення судової практики розгляду господарськими судами справ щодо корпоративних спорів, корпоративних прав та цінних паперів за період з 01.01.2018 по 30.11.2018 p. URL: https://supreme.court.gov.ua/ userfiles/media/Oglyad_korpor_spori.pdf (дата звернення: 05.03.2019).

12. Маковская А. А. Правовые последствия недействительности решений общего собрания акционеров и совета директоров акционерного общества. Недействительность в гражданском праве:проблемы, тендениии, практика : сборник статей / отв. ред. М. А. Рожкова. Москва: Статут, 2006. С. 353.

13. Беляневич О. А., Мягкий А. В. Корпоративне управління за законодавством України: теоретико-прикладні проблеми : монографія. Київ : НДІ приватного права і підприємництва імені академіка Ф. Г. Бурчака НАПрН України, 2017. C. 252.

The article focuses on the specifics of the application of such a method of protection of corporate rights, as the invalidation of decisions of bodies of management of a company. Its effectiveness and expediency of isolation within other methods of protection are substantiated. Emphasis is placed on the separation of powers of the general meeting and the executive body in the system of governing bodies of a company. The prevailing in the national legislation the powers of the general meeting over other bodies of the company.

It is emphasized that the unconditional grounds for the application of such a method of protection, as the right to demand the invalidation of decisions of the governing bodies of a company, may be: absence of quorum at the general meeting; violation of the agenda of their convening, decision-making on issues that have not been put on the agenda; holding meetings elsewhere and at a time other than stated in the notice; 
lack of minutes of the general meeting of the LLC; absence of the minutes of the general meeting of the jointstock company, signed by the chairman and the secretary of the meeting, etc. Instead, formal grounds for the application of this method of protection may be the non-admission of a participant to the general meeting, when the decision that led to the loss of such participant, etc. The application of this method of protection without proper grounds may lead to the blocking of important decisions for the activity of the company, which will adversely affect its business activities. That is why the right to appeal against decisions of bodies of a company is subject to the effect of the fixed legislative restrictions, which stipulate observance of such conditions as the inconsistency of the decisions of the general meeting with the norms of legislation; violation of the requirements of the law and / or constituent documents during the convocation and holding of the general meeting of the company; depriving a member (shareholder, member) of the company of the opportunity to participate in the general meeting. The above conditions are predominantly procedural in nature and may not always be grounds for invalidation of decisions taken at a general meeting.

The legal nature of the decisions of the governing bodies of business societies as non-normative acts is established. The provisions of Art. 203 and 215 of the Civil Code of Ukraine, which determine the grounds for the invalidity of the transaction, and, accordingly, the legal consequences of the invalidity of the transaction under Art. 216 of the Central Committee of Ukraine. The classification of decisions of the governing bodies of companies is proposed according to the criterion of materiality of the committed violation and their consequences.

Key words: corporate law, governing body of a company, method of protection, decision of general meeting, decision of executive body, grounds for application of method of protection, appeal against decisions of general meeting. 